\title{
MOTIVASI KERJA TENAGA KESEHATAN DI PUSKESMAS PANAMBUNGAN KOTA MAKASSAR
}

\section{The Work Motivation Of Health Workers At Panambungan Health Center, Makassar City}

\author{
Bertolomeus Arin $^{1}$, Indar ${ }^{2}$, Lusyana Aripa ${ }^{3}$, Hardianto Haris ${ }^{4}$ \\ ${ }^{1,3,4}$ Fakultas Kesehatan Masyarakat Universitas Pancaskti Makassar \\ ${ }^{2}$ Fakultas Kesehatan Masyarakat Universitas Hasanudin
}

Korespondensi: bertolomeusarin1@gmail.com

\begin{abstract}
ABSTRAK
Daya pendorong yang mengakibatkan seseorang anggota organisasi mau dan rela untuk menggerakkan kemampuan dalam membentuk keahlian dan keterampilan tenaga dan waktunya untuk menyelenggarakan berbagai kegiatan yang menjadi tanggung jawabnya dan menunaikan kewajibannya dalam rangka pencapaian tujuan dan berbagai sasaran organisasi yang telah ditentukan sebelumnya. Berdasarkan observasi awal pada tenaga kesehatan di Puskesmas Panambungan Kecamatan Mariso Kota Makassar, Tujuan penelitian untuk mengetahui secara mendalam motivasi kerja tenaga kesehatan di Puskesmas Panambungan Kecamatan Mariso Kota Makassar. Penelitian ini menggunakan pendekatan kualitatif yang sifatnya deskriptif. Pengumpulan data dalam penelitian ini diperoleh melalui teknik wawancara mendalam dan observasi atau pengamatan. Penentuan subjek penelitian dengan purposive sampling dengan kriteria semua tenaga kesehatan di Puskesmas Panambungan Kecamatan Mariso Kota Makassar, tenaga kesehatan yang bersedia untuk diwawancarai di Puskesmas Panambungan Kecamatan Mariso Kota Makassar, dari 23 orang tenaga kesehatan di Puskesmas Panambungan Kecamatan Mariso Kota Makassar, minimal 5 orang yang menjadi informan. Hasil penelitian motivasi kerja tenaga kesehatan karena gaji yang cukup, lingkungan kerja yang bersih dan nyaman, adanya hubungan yang baik sesama rekan kerja, keselamatan kerja sesuai standar yang telah ditetapkan, terciptanya etika dalam bekerja. Diharapkan bagi puskesmas perlu adanya penambahan fasilitas, penambahan ruangan kerja, agar meningkatkan motivasi kerja bagi tenaga kesehatan di puskesmas panambungan.
\end{abstract}

Kata kunci: Kebutuhan fisiologis, keamanan kerja, penghargaan

\section{ABSTRACT}

The driving force can cause members of the organization to be willing to maximize their ability and time to carry out various activities that become their responsibility and to achieve the goals and objectives of the organization that have been predetermined. Based on preliminary observations on health workers at Panambungan Health Center, Mariso, Makassar, it was found inadequate facilities, lack of appreciation given to health workers, and the narrow space of working. This study aimed to find out deeply the work motivation of the health workers at Panambungan Health Center, Mariso, Makassar. This study applied a descriptive qualitative approach. Data in this study were collected through in-depth interviews and observations. Samples were selected using purposive sampling based on certain criteria, namely, health workers who worked at Panambungan Health Center, Mariso, Makassar, and were willing to be interviewed at Panambungan Health Center, Mariso, Makassar. From 23 health workers, 5 people were selected to be informants. The result of the study indicated that the work motivation of health workers was sufficient wages, a clean and comfortable work environment, good relationships among colleagues, work safety according to predetermined standards, and work ethics. It is expected that the health center needs to add facilities, the addition of work space, in order to increase work motivation for health workers in the health center panambungan.

Keywords: physiological needs, job security, appreciation. 


\section{PENDAHULUAN}

Motivasi kerja adalah dorongan atau kehendak yang mempengaruhi perilaku tenaga kerja untuk dapat meningkatkan kinerja. Lingkungan kerja adalah persepsi anggota organisasi secara individual maupun kelompok dan mereka yang secara tepat berhubung internal dengan organisasi. Menurut (Sedarmayanti, 2009) dalam (Librianty, 2018).

Kinerja merupakan hal penting yang harus dicapai oleh setiap instansi karena kinerja merupakan cerminan bagi kemampuan setiap instansi dalam mengelola dan mengalokasikan pegawainya, oleh karena itu kinerja para pegawai mempunyai pengaruh yang sangat penting bagi berlangsungnya kegiatan instansi dan berpengaruh bagi proses pencapaian tujuan instansi (Widiyanti, 2015).

Motivasi biasanya timbul karena adanya kebutuhan yang belum terpenuhi, tujuan yang ingin dicapai, atau karena adanya harapan yang diinginkan. Motivasi kerja merupakan kombinasi kekuatan psikologis yang kompleks dalam diri masing-masing orang. Motivasi adalah keinginan untuk bertindak. Setiap orang dapat termotivasi oleh beberapa kekuatan yang berbeda, (Robert Heller, 1998) dalam (Tanuwibowo, 2013).

Peraturan Menteri Kesehatan Nomor 75 Tahun 2014, pada lampiran romawi V tentang standar ketenagaan puskesmas nonrawat inap puskesmas kawasan perkotaan disebutkan bahwa kondisi minimal 22 orang yang diharapkan agar kegiatan puskesmas dapat diselenggarakan dengan baik. Diantaranya: dokter atau dokter layanan primer lorang, dokter gigi 1orang, perawat 5orang, bidan 4orang, tenaga kesehatan masyarakat 2 orang, tenaga kesehatan lingkungan 1orang, ahli teknologi laboratorium medik 1orang, tenaga gizi 1orang, tenaga kefarmasian 1orang, tenaga administrasi 3orang, pekarya 2orang (Kemenkes, 2014).

Menurut Permenkes Nomor 75 Tahun 2014, Pusat Kesehatan Masyarakat yang selanjutnya disebut Puskesmas adalah fasilitas pelayanan kesehatan yang menyelenggarakan upaya kesehatan masyarakat dan upaya kesehatan perseorangan tingkat pertama, dengan lebih mengutamakan upaya promotif dan preventif, untuk mencapai derajat kesehatan masyarakat yang setinggi-tingginya di wilayah kerjanya. Konsep puskesmas di lahirkan pada tahun 1968, maka mulailah di bangun puskesmas di beberapa wilayah yang dipimpin oleh seorang dokter wilayah (Kanwil) yang membawahi beberapa kecamatan (Permenkes 2014).

Puskesmas Panambungan memiliki 24 tenaga kerja kesehatan diantaranya Kepala Puskesmas, 1 KTU 1 Dokter Gigi Madya, 1 Bidan Madya, 1 Perawat Gigi Madya, 1 Dokter Muda, 1 Nutrisionis, 1 apoteker Ahli Muda, 1 Sanitarian Penyelia,1 Perawat Gigi Penyelia, 2 Perawat Muda, 1 Penyuluhan Kesehatan Masyarakat Muda, 1 Ass. Apoteker Penyelia, 1 Pranata Labkes Muda, 1 Perekam Medis Pelaksana Lanjutan, 1 Nutrisionis Pelaksana Lanjutan, 2 Perawat Pertama, 1 Bidan Pelaksana Lanjutan, 2 Perawat Pelaksana 
Lanjutan, 2 Bidan Terampil, (Profil Puskesmas

Panambungan 2019). Berdasarkan data

Puskesmas Panambungan Kecamatan Mariso

Kota Makassar pada tahun 2019 jumlah tenaga

kesehatan sebanyak 23 orang, diantaranya 15 orang PNS dan 8 orang non-PNS. Setiap pegawai mengerjakan tugas yang berbeda-beda sesuai dengan pekerjaan masing-masing. Wilayah kerja Puskesmas Panambungan meliputi, 3 (tiga) kelurahan yaitu Kelurahan Panambungan, Kelurahan Mario, dan Kelurahan Kunjung Mae (Profil Puskesmas Panambungan 2019).

Berdasarkan hasil pengamatan atau observasi awal, peneliti menemukan fasilitas kurang memadai, seperti: di ruangan poli umum belum adanya pengeras suara untuk panggilan antrian pasien, luas ruangan kerja yang sempit, contohnya di loket Obat, sebagian obat masih membutuhkan rak penyimpanan, loket pendaftaran masih menggunakan manual. Hal ini dapat mempengaruhi motivasi kerja tenaga kesehatan dan akan memberi dampak dalam proses pemberian pelayanan terhadap pasien, seperti yang ditemukan melalui kotak saran, yang dimana terdapat begitu banyak keluhan masyarakat yang berkaitan dengan sistem pelayanan yang kurang baik (Pelayanan lambat dan kurang ramah terhadap pasien).

\section{BAHAN DAN METODE}

Penelitian ini menggunakan pendekatan kualitatif yang sifatnya deskriptif karena bertujuan mendeskripsikan atau memperoleh informasi atau data mengenai keadaan saat ini atau fenomena yang dialami oleh subjek yang diteliti secara mendalam mengenai Motivasi Kerja Tenaga Kesehatan di Puskesmas Panambungan Kecamatan Mariso Kota Makassar.

Penelitian ini dilaksanakan di Puskesmas Panambungan Kota Makassar pada bulan November 2020. Penentuan subjek dengan menggunakan purposive sampling dengan kriteria semua tenaga kesehatan di Puskesmas Panambungan Kecamatan Mariso Kota Makassar. Tenaga kesehatan yang bersedia untuk diwawancarai dan dari 23 orang tenaga kesehatan di Puskesmas Panambungan Kecamatan Mariso Kota Makassar, minimal 5 orang yang menjadi informan.

Sumber data primer diperoleh melalui teknik wawancara mendalam dan observasi atau pengamatan serta data skunder diperoleh dari catatan atau laporan yang tersusun dalam arsip (dokumen) instansi yang berkaitan dengan topik penelitian. Teknik pengolahan data yang telah diperoleh dari kuesioner pada penelitian ini adalah menggunakan komputer program SPSS dan data tersebut kemudian diolah dengan prosedur pengolahan data. Tujuan penelitian ini untuk mengetahui secara mendalam motivasi kerja tenaga kesehatan di Puskesmas Panambungan Kecamatan Mariso Kota Makassar.

\section{HASIL}

Informan dalam penelitian ini adalah tenaga kesehatan yang bekerja di Puskesmas 
http://journal.unpacti.ac.id/index.php/JPP

Panambungan Kecamatan Mariso Kota

laki-laki 2 orang dan perempuan 3 orang. Rata-

Makassar. Karakteristik informan mencakup rata usia informan dalam penelitian 24 sampai jenis kelamin, pekerjaan dan pendidikan. Informan yang berhasil diwawancarai oleh 48 tahun dan berjenis kelamin laki-laki dan peneliti berjumlah 5 orang, yang terdiri dari perempuan.

\section{Tabel 1 Karakteristik Informan}

\begin{tabular}{ccccc}
\hline Inansial & Usia & Jenis Kelamin & Pekerjaan & Pendidikan \\
\hline AE & 39 & Perempuan & PNS & S2 \\
FW & 35 & Perempuan & PNS & S 1 \\
SH & 48 & Laki-laki & PNS & S1 \\
MM & 25 & Laki-laki & Non-PNS & D3 \\
RK & 24 & Perempuan & Non-PNS & D3 \\
\hline
\end{tabular}

Sumber: Data Primer, 2020

\section{Kerangka Hasil Penelitian}

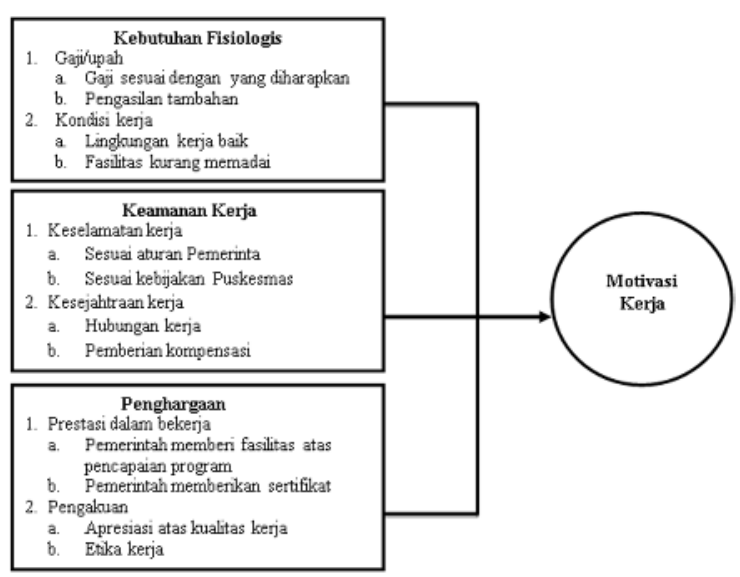

\section{Gambar 1. Kerangka Hasil Penelitian (Bertolomeus, 2020)}

Motivasi kerja tenaga kesehatan di Puskesmas Panambungan Kecamatan Mariso Kota Makassar, dipengaruhi oleh adanya kebutuhan fisiologis, keamanan kerja, dan penghargaan. Kebutuhan fisiologis adalah adalah pengkondisian udara dan cahaya, kondisi kerja, serta gaji atau upah yang diberikan oleh organisasi untuk melaksanakan tugas dan kewajiban pegawai (Tenaga kesehatan).
Kebutuhan fisiologis tentang gaji/upah meliputi gaji sesuai yang diharapkan, penghasilan tambahan. Adapun kebutuhan fisiologi tentang kondisi kerja adalah sebagai berikut: lingkungan kerja baik dan fasilitas tidak memadai. Tingkat motivasi kerja dipengaruhi keamanan kerja. Keamanan kerja merupakan Keamanan kerja bagi pegawai (Tenaga kesehatan) merupakan faktor yang sangat penting yang perlu diperhatikan oleh pimpinan/organisasi. Kondisi kerja yang aman akan membuat pegawai (Tenaga kesehatan) tenang dalam bekerja, sehingga berdampak meningkatnya produktivitas pegawai.

Selain kebutuhan fisiologis, keamanan kerja dan penghargaan juga mempengaruhi motivasi kerja tenaga kesehatan di Puskesmas Panambungan Kecamatan Mariso Kota Makassar, yang dimana penghargaan meliputi: prestasi dalam bekerja dan pengakuan.

\section{PEMBAHASAN}

Dari hasil wawancara mendalam yang 
diperoleh dari informan, maka dibuatlah suatu pembahasan dari setiap variabel yang diteliti, sebagai berikut:

\section{Pengertian Kebutuhan Fisiologis}

Fisiologis dalam penelitian ini yaitu kebutuhan tenaga kesehatan yang berhubungan dengan kebutuhan utama, dasar yang harus terpenuhi oleh manusia untuk mempertahankan diri dari setiap individu. Adapun faktor lain yang mencakup kebutuhan ini yaitu pengkondisian udara dan cahaya, kondisi kerja (tenang, nyaman, penataan ruangan yang baik) serta Gaji atau upah untuk memenuhi kebutuhan sehari-hari, (Adelina, 2018).

\section{Gaji/upah}

Hasil wawancara mendalam gaji/upah, terbagi menjadi dua (2) bagian yaitu:.

\section{Gaji sesuai dengan yang diharapkan}

Menurut (Indriyani, 2014), Pemberian gaji akan berpengaruh terhadap semangat kerja karyawan ini disebabkan karena uang masih merupakan motivator yang kuat bagi karyawan. Maka setiap perusahaan perlu memperhatikan mengenai gaji dan tunjangan kesejahteraan yang banyak diharapkan dari pada karyawan.

Hal ini sejalan dengan penelitian yang dilakukan (Masuku, 2013) Hasil penelitian ini menunjukkan, informan menganggap bahwa lingkungan kerjanya sudah aman dan nyaman. Penghasilan yang diterima telah mencukupi kebutuhan hidup sehari-hari. Pegawai juga tidak berpartisipasi langsung dalam penyusunan program kerja. Kesimpulan dari penelitian ini adalah bahwa lingkungan kerja dokter PNS sudah aman dan nyaman begitu juga dengan penerimaan dan kerjasama dengan rekan kerjanya. Penghasilan yang diterima oleh dokter PNS telah mencukupi kebutuhan hidup.

\section{Penghasilan tambahan}

Menurut (Yalitoba, 2019), Pemberian tambahan penghasilan tersebut bersifat rutin diterima pegawai setiap bulannya, sehingga memberi semangat atau motivasi kerja yang lebih baik lagi, serta berdampak terhadap kinerja yang dihasilkan. Tambahan Penghasilan Pegawai adalah tambahan penghasilan bagi pegawai negeri sipil yang diberikan di luar gaji berdasarkan kriteria tertentu, yang bertujuan tidak hanya untuk meningkatkan kinerja pegawai dan memberikan motivasi agar pegawai lebih disiplin, akan tetapi dalam rangka pembangunan daerah.

Hal ini sejalan dengan penelitian yang dilakukan (Yalitoba, 2019), terdapat hasil penelitian, terbukti bahwa tambahan penghasilan mempunyai pengaruh yang positif dan signifikan sebesar 79\% terhadap kinerja pegawai Sekretariat Daerah Kabupaten Sigi. Oleh karena itu terwujudnya kinerja pegawai Sekretariat Daerah Kabupaten Sigi salah satunya ditentukan oleh dukungan tambahan penghasilan yang baik di lingkungan Sekretariat Daerah Kabupaten Sigi. Sebagaimana dikemukakan oleh Mangkunegara (2013:67), bahwa kinerja pegawai adalah hasil kerja secara kualitas dan kuantitas yang dicapai oleh seorang pegawai dalam melaksanakan tugasnya sesuai dengan 
tanggung jawab yang diberikan kepadanya.

\section{Kondisi kerja}

Hasil wawancara mendalam kondisi kerja terbagi menjadi dua (2) bagian yaitu:

\section{Lingkungan kerja baik}

Menurut (Mahleni Dkk, 2019) Lingkungan kerja adalah segala sesuatu yang ada di sekitar para pekerja/pegawai yang dapat mempengaruhi kepuasan kerja karyawan dalam melaksanakan pekerjaannya sehingga akan diperoleh hasil kerja yang maksimal, dimana dalam lingkungan kerja tersebut terdapat fasilitas kerja yang mendukung pegawai dalam penyelesaian tugas yang dibebankan kepada pegawai guna meningkatkan kerja pegawai dalam suatu organisasi.

Hal ini sesuai juga dengan hasil penelitian yang dilakukan (Mahleni Dkk, 2018) menunjukan bahwa semakin baik kondisi lingkungan kerja seperti penerangan, sirkulasi udara, suara bising, keamanan ditempat kerja, hubungan karyawan pada Puskesmas Gambir Baru Kabupaten Asahan telah terpenuhi maka akan meningkatkan kinerja pegawai. Seperti yang dikemukakan oleh Ardana lingkungan kerja yang aman dan nyaman terbukti berpengaruh terhadap produktivitas karyawan. Sebagai lingkungan kerja yang memberikan kesempatan kepada tenaga kesehatan untuk berkarya Puskesmas Gambir Baru Kecamatan Kota Kisaran Timur mengharapkan lingkungan kerja yang ada dapat memacu kinerja yang baik para tenaga kesehatan, terutama mereka yang terkait dalam aktivitas pelayanan. Untuk itu, penting bagi para tenaga kesehatan untuk menjaga dan meningkatkan kinerja yang dimiliki dalam lingkungan kerja yang dimiliki.

\section{Fasilitas kurang memadai}

Penyediaan fasilitas kesehatan merupakan salah satu upaya pemerintah dalam meningkatkan mutu kesehatan masyarakat, dan menjadi kewajiban pemerintah untuk menyediakan fasilitas pelayanan kesehatan yang layak bagi setiap warga negara. Fasilitas fisik merupakan salah satu ukuran untuk melakukan penilaian terhadap kinerja Puskesmas. Demikian juga fasilitas fisik merupakan faktor yang penting yang mempengaruhi kepuasan pasien atau pelanggan puskesmas. Pasien cenderung menilai kualitas pelayanan yang dilaksanakan Puskesmas dengan alat indranya untuk menilai fasilitas secara fisik karena pasien tidak mampu menilai pelayanan kesehatan dari aspek pengetahuan maupun keterampilan petugas. Berdasarkan hasil penelitian Hartati (2007), menemukan bahwa sebagian besar responden menyatakan tidak puas dengan kenyataan yang ada di puskesmas, yaitu fasilitas fisik dan lingkungan puskesmas yang tidak memadai, (Rukmini, Dkk, 2012).

Hal ini sejalan dengan (Rensiner, Dkk, 2018) yang dimana terdapat hasil wawancara mendalam dengan bidang pelayanan penunjang, permasalahan di apotek sampai sekarang terkait dengan ruangan yang sangat sempit, termasuk ruang tunggu. Hal ini sebetulnya sudah dibicarakan pada pertemuan Pemda Kabupaten, namun untuk pembangunan 
gedung farmasi sampai sekarang belum dianggarkan. Menurut SPM standar waktu tunggu pelayanan obat dibagi menjadi dua, yaitu obat jadi dengan standar waktu maksimal 30 menit dan obat racikan dengan standar waktu maksimal 60 menit. 10 Penelitian yang dilakukan oleh Fitriah dkk. (2016), tentang Penyebab dan Solusi Lama Waktu Tunggu Pelayanan Obat di Instalasi Farmasi Rawat Jalan didapatkan hasil : sejak pasien meletakkan resep hingga proses entri dilakukan dibutuhkan waktu rata-rata 20 menit pada saat jam sibuk, sedangkan proses entri resep sendiri untuk satu resep rata-rata membutuhkan waktu 2 menit.

\section{Pengertian Keamanan kerja}

Keamanan kerja adalah suatu usaha untuk menjaga dan melindungi pekerja dan fasilitas/aset yang dimiliki, baik yang berada di dalam Kantor maupun yang berada di luar lingkungan Kantor. Upaya memberikan jaminan keamanan kerja tidak hanya diperuntukkan bagi tenaga kerja yang bekerja di dalam lingkungan Kantor, tetapi juga bagi tenaga kerja yang bekerja di lapangan, misalnya: Pegawai bank yang bertugas mengambil atau mengantarkan uang ke suatu tempat perlu mendapat pengawalan yang ketat untuk mengantisipasi tindak kejahatan, (Safriansyah, Naim, 2019).

\section{Keselamatan kerja}

Berdasarkan hasil wawancara mendalam keselamatan kerja terdapat dua (2) bagian:

\section{Sesuai aturan pemerintah}

Standar operasional prosedur (SOP) adalah pedoman atau acuan untuk melaksanakan tugas dan pekerjaaan sesuai dengan fungsi dari pekerjaan tersebut. Dengan adanya SOP semua kegiatan di suatu perusahaan dapat terancang dengan baik dan dapat berjalan sesuai kemauan perusahaan. SOP dapat didefinisikan sebagai dokumen yang menjabarkan aktivitas operasional yang dilakukan sehari-hari, dengan tujuan agar pekerjaan tersebut dilakukan secara benar, tepat, dan konsisten, untuk menghasilkan produk sesuai standar yang telah ditetapkan, (Gabriele, 2018).

Dari hasil penelitian yang dilakukan, (Muttaqin, Sumiati, 2019), menyatakan bahwa Hasil penelitian disimpulkan bahwa pelaksanaan Standar Operasional Prosedur (SOP) berdasarkan akumulasi jawaban responden rata-rata menunjukan hasil baik, yaitu mencapai $74,68 \%$. Adapun pencapaian Kualitas pelayanan rawat jalan menunjukan hasil rata rata baik yaitu mencapai 76,72\%.

\section{Sesuai kebijakan puskesmas}

Sebagai upaya pemerintah untuk mendorong agar fasilitas pelayanan kesehatan mengutamakan pelayanan, keselamatan dan perlindungan kepada masyarakat adalah salah satunya dengan mewajibkan setiap instansi kesehatan untuk menerapkan budaya keselamatan dan kesehatan kerja sesuai dengan Permenkes No 52 Tahun 2018 tentang Keselamatan dan Kesehatan Kerja di Fasilitas Pelayanan Kesehatan. Dalam peraturan 
tersebutkan disebutkan dan dijelaskan bagaimana setiap fasilitas pelayanan kesehatan harus memenuhi standar yang sudah ditetapkan, dan apabila ada beberapa aspek yang tidak dipenuhi akan menimbulkan kecelakaan kerja. Kecelakaan kerja secara umum disebabkan oleh 2 hal pokok yaitu perilaku tidak aman (unsafe behavior/unsafe action) dan kondisi tidak aman (unsafe condition) (Sipayung dkk, 2015), dalam (Rifai, 2020).

Berdasarkan hasil penelitian yang dilakukan (Afrilyani, Dkk, 2019) hasil penemuan dilapangan bahwa pengetahuan diperoleh, dari SOP Penggunaan Alat Pelindung diri. Selain itu adanya sosialisasi penggunaan Alat Pelindung Diri yang dilakukan oleh kepala rumah sakit setiap upacara pagi menyampaikan untuk menggunakan alat pelindung diri pada saat bekerja dan mengingatkan petugas untuk membaca SOP tersebut sebelum memulai aktivitas di unit laboratorium, guna untuk memberikan pengetahuan mengenai Alat Pelindung Diri sehingga petugas memiliki pengetahuan yang baik mengenai Alat Pelindung Diri.

\section{Kesejahteraan kerja}

Dari hasil wawancara mendalam yang dilakukan peneliti dimana kesejahteraan kerja ini, dibagi menjadi dua (2) bagian yaitu:

\section{Hubungan yang baik}

Pada dasarnya, faktor-faktor yang mempengaruhi timbulnya kualitas pelayanan cukup kompleks dan saling terikat satu sama lain. Salah satu faktor yang mempengaruhi kualitas pelayanan adalah kerjasama tim. Kerjasama tim adalah kemampuan antar individu untuk membentuk dan mengelola tim. Perilaku manusia dalam berbagai situasi kerja menyimpulkan bahwa hubungan antar manusia diantara anggota tim lebih penting dalam menentukan produktivitas dari pada perubahan kondisi kerja, (Riana, 2019).

Dalam penelitian yang dilakukan (Riana, 2019) penelitian yang terbukti memiliki pengaruh terhadap kualitas pelayanan pada perawat. Kerjasama tim merupakan kemampuan antar individu untuk membentuk dan mengelola tim. Perilaku manusia dalam berbagai situasi kerja menyimpulkan bahwa hubungan antar manusia diantara anggota tim lebih penting dalam menentukan produktivitas dari pada perubahan kondisi kerja. Dalam penelitiannya yang perlu diperhatikan untuk meningkatkan produktivitas organisasi adalah moral kerja karyawan, dinamika kelompok, pengawasan yang demokratis, dan hubungan antar karyawan (Malec dkk, 2007). Oleh karena itu, perawat yang memiliki kerjasama tim yang baik maka ia akan memiliki kecenderungan untuk dapat meningkatkan kualitas pelayanan di tempat kerja dikarenakan individu merasa bahwa pekerjaan yang dilakukannya memiliki makna bagi kehidupannya, tumbuhnya rasa kebersamaan karena bisa membantu rekan timnya dalam menyelesaikan pekerjaannya, hal tersebut secara psikologis mendorong keinginan perawat untuk meningkatkan kualitas pelayanannya kepada pasien. 


\section{Pemberian kompensasi}

Pemberian kompensasi pada dasarnya bertujuan untuk mendorong pekerja agar bekerja lebih baik sehingga merasa puas dalam bekerja. Kompensasi yang baik adalah kompensasi yang mampu menjamin kepuasan kerja pegawai sehingga memungkinkan organisasi untuk memperoleh, memelihara dan mempekerjakan pegawai dengan sikap dan perilaku yang positif dan mampu meningkatkan kinerja dalam bekerja, (Wirajaya, Dkk, 2016).

Berdasarkan hasil penelitian yang dilakukan (Hendayani, 2018), dapat diketahui bahwa: Pengaruh Pemberian Kompensasi Pada Pelayanan Publik di Desa Jalatrang Kecamatan Cipaku Kabupaten Ciamis telah dilaksanakan dengan cukup. Artinya Pemberian Kompensasi Pada Pelayanan Publik di Desa Jalatrang Kecamatan Cipaku Kabupaten Ciamis telah dilaksanakan dengan baik.

\section{Pengertian Penghargaan}

Penghargaan merupakan imbalan yang diberikan oleh perusahaan terhadap karyawannya atas pekerjaan yang telah dilakukannya, baik penghargaan yang bersifat intrinsik maupun ekstrinsik. Dengan adanya penghargaan yang baik diharapkan pegawai mampu meningkatkan kinerja serta lebih memiliki keinginan yang tinggi untuk unggul dalam melakukan pekerjaan dan memiliki kemampuan untuk berkompetisi sehingga tercapai keseimbangan antara tujuan pribadi dan organisasi. Karena di lain sisi, penghargaan yang baik pun juga bisa menjadi motivasi tersendiri bagi karyawan tersebut untuk mencapai kinerja yang baik kedepannya, (Prabu, 2016).

\section{Prestasi dalam bekerja}

Dari hasil wawancara mendalam yang dilakukan peneliti dimana kesejahteraan kerja ini, dibagi menjadi dua (2) bagian yaitu:

\section{Pemerintah Memberi Fasilitas Atas Pencapaian Program Dan Pemerintah Memberikan Sertifikat}

Menteri Kesehatan RI, Nila Farid

Moeloek memberikan penghargaan kepada 163 (Nakes) sebagai Nakes teladan Puskesmas. Penghargaan itu diberikan berkat prestasi dan dedikasinya dalam memberikan pelayanan kesehatan yang terbaik kepada masyarakat. Tenaga Kesehatan teladan itu dipilih dari 34 provinsi. Ada 9 jenis tenaga kesehatan yang dipilih yakni terdiri dari dokter atau dokter layanan primer, dokter gigi, perawat, bidan, tenaga kesehatan masyarakat, tenaga kesehatan lingkungan, ahli teknologi laboratorium medik, tenaga gizi dan tenaga kefarmasian. Masingmasing Nakes teladan mendapatkan sertifikat dan 1 unit laptop. Penghargaan itu diberikan secara simbolis oleh Menkes Nila didampingi PLT Kepala Badan Pengembangan dan Pemberdayaan SDM Kesehatan, Siswanto kepada 9 Nakes. Penghargaan yang diberikan kepada tenaga kesehatan teladan di Puskesmas Tahun 2018 mencerminkan rasa terima kasih dan pengakuan Pemerintah atas keteladanan dalam pelayanan kesehatan, (P2PTM Kemenkes RI, 2018).

\section{Pengakuan}

Berdasarkan wawancara mendalam 
yang dilakukan peneliti, dimana pengakuan dibagi menjadi dua (2) bagian, yaitu:

\section{Apresiasi atas kualitas kerja}

Tenaga kesehatan berperan besar dalam menentukan pembangunan kesehatan. Di Indonesia, terdapat ribuan tenaga kesehatan di Puskesmas yang telah bekerja dengan sungguh-sungguh dan menunjukkan prestasi kerja yang sebaik-baiknya. Mereka adalah pahlawan bangsa yang menunaikan tugasnya untuk mencapai visi kita bersama, yaitu masyarakat sehat yang mandiri dan berkeadilan.

\section{Demikian pernyataan Menteri}

Kesehatan RI, dr. Nafsiah Mboi, Sp.A, MPH, di hadapan 130 tenaga kesehatan (Nakes) teladan di Puskesmas tingkat Nasional 2012, di Kantor Kementerian Kesehatan RI. "Saya yakin, prestasi yang diraih merupakan hasil kerja keras dalam menerapkan nilai-nilai pro-rakyat, cepat-tepat, teamwork, dengan integritas yang tinggi, dan secara akuntabel (transparansi). Di masa mendatang, tugas Saudara bertambah berat dengan menyandang predikat teladan, karena dituntut untuk mempertahankan dan meningkatkan prestasi yang telah dicapai, serta harus dapat memotivasi bahkan menjadi panutan bagi petugas kesehatan di sekitar Saudara".

Kepala Pusat Promosi Kesehatan Kemenkes RI, dr. Lily selaku Ketua Panitia Penyelenggara, mengatakan bahwa pemilihan Nakes Teladan rutin diselenggarakan setiap tahun, bertepatan dengan ulang tahun Kemerdekaan RI. Dalam laporannya, dr. Lily mengatakan bahwa pemberian penghargaan kepada tenaga kesehatan teladan merupakan apresiasi serta bentuk penghargaan dari Kementerian Kesehatan RI kepada tenaga kesehatan di Puskesmas atas pengabdian dan prestasinya dalam memberikan pelayanan kesehatan kepada masyarakat, khususnya di lokasi tempat mereka bertugas. "Tenaga kesehatan teladan, memiliki prestasi yang membanggakan dan kontribusi yang besar dalam pelaksanaan 3 fungsi Puskesmas, yaitu sebagai penggerak pembangunan berwawasan kesehatan, penggerak pemberdayaan masyarakat dan pemberi pelayanan kesehatan strata pertama". Pemilihan tenaga kesehatan dilakukan secara selektif melalui serangkaian kegiatan yang meliputi penelaahan, pemeriksaan, penelitian dan penilaian oleh para ahli dan organisasi profesi terkait, yang hasilnya tercermin pada pengetahuan, sikap, perilaku, dan karya masing-masing individu teladan. "Selain itu, kegiatan ini juga sebagai motivasi bagi para tenaga kesehatan untuk meningkatkan kinerja dan terus memberikan pelayanan kesehatan secara prima kepada masyarakat, (Rokom, 2012).

\section{Etika kerja}

Suatu perusahaan maupun instansi pemerintahan dalam menyelesaikan pekerjaan ataupun untuk mewujudkan tujuan agar hasilnya baik, efektif, efisien dan sesuai dengan yang diharapkan maka dibutuhkan kerja tim (teamwork). Salah satu instansi yang menerapkan dan menjalankan kerja tim (teamwork) antara lain adalah instansi dalam 
lingkup kesehatan. Salah satu instansi yang bekerja dengan kerja tim, antara lain adalah Rumah Sakit maupun puskesmas Dapat dipastikan bahwa suatu instansi Rumah Sakit maupun puskesmas pasti didalamnya ada struktur organisasi, serta di dalamnya pasti mempunyai budaya organisasi yang merupakan suatu ciri khas dari sebuah instansi satu dengan yang lainnya, dalam (Rahma, 2016).

Adapun hasil penelitian yang dilakukan (Rahma, 2016), yang dimana terdapat teamwork dan budaya organisasi terhadap kinerja perawat di RSUD Sunan Kalijaga. Dalam hal ini dapat dijelaskan bahwa kerja tim/ teamwork yang sangat baik akan mendukung terwujudnya kinerja yang baik dari perawat. Selain itu, kinerja perawat juga ditentukan oleh budaya organisasi yang dijalankan oleh team itu sendiri. Artinya jika ada peningkatan dari budaya organisasi maka meningkat pula kinerja dari perawat itu sendiri. Team work dan budaya organisasi menjadi faktor penting dalam peningkatan kinerja perawat, khususnya di RSUD Sunan Kalijaga. Namun hal yang sangat penting adalah bagaimana perawat memahami teamwork itu sendiri. Aplikasi team work dengan pemahaman yang tepat akan menumbuhkan budaya organisasi yang baik. Sehingga lahirlah kinerja perawat yang menjadikan organisasi terus berkembang (Khatimah. K, 2020).

\section{KESIMPULAN DAN SARAN}

Kesimpulan penelitian yaitu motivasi kerja tenaga kesehatan di Puskesmas Panambungan karena kebutuhan fisiologis, dimana gaji/upah yang cukup dan kondisi kerja yang baik memberi motivasi kerja kepada tenaga kesehatan di Puskesmas Panambungan Kecamatan Mariso Kota Makassar.

Keamanan kerja: keselamatan kerja tenaga kesehatan di puskesmas panambungan terjamin. Hubungan yang baik antara pemimpin maupun rekan sekerja serta pemberian kompensasi terhadap tenaga kesehatan, juga dapat memberi motivasi kerja. Penghargaan: pemberian fasilitas (komputer/ laptop), serta sertifikat dari pemerintah merupakan bentuk penghargaan atas prestasi dalam pencapaian program sehingga memberikan motivasi kerja terhadap tenaga kesehatan di puskesmas panambungan. Penilaian dari pemimpin terhadap tenaga kesehatan dalam bentuk rapor tahunan juga memberikan motivasi kerja tenaga kesehatan di Puskesmas Panambungan Kecamatan Mariso Kota Makassar.

Diharapkan agar seluruh tenaga kesehatan tetap mempertahankan dan terus meningkatkan prestasi yang ada, demi meningkatkan derajat kesehatan masyarakat. Dan perlunya penambahan fasilitas, penambahan ruangan kerja, demi meningkatkan motivasi kerja bagi tenaga kesehatan di Puskesmas Panambungan.

\section{DAFTAR PUSTAKA}

Khatimah, K. (2020). Kinerja Perawat di RSUD H. Padjonga Dg. Ngalle Kabupaten Takalar. Jurnal Promotif Preventif, 3(1), 36-46.

Gabriele. (2018). Analisis Penerapan Standar 
Operasional Prosedur (Sop) Di

Departemen Marketing Dan Hrd Pt Cahaya Indo Persada. Jurnal Agora Vol 6. No. 1 Surabaya.

Hendayani. (2018). Pengaruh Pemberian Kompensasi Terhadap Kinerja Pegawai Pada Pelayanan Publik Di Desa Jalatrang Kecamatan Cipaku Kabupaten

Ciamis. Fakultas Ilmu Sosial Dan Ilmu Politik Universitas Galuh. Ciamis.

Masuku. (2013). Analisis Motivasi Kerja Dokter Pegawai Negeri Sipil Di Kabupaten Kepulauan Sula. Jurnal MKMI. Maluku utara.

Muttaqin, Sumiati, (2019). Pelaksanaan Standar Operasional Prosedur Dalam Meningkatkan Pelayanan Rawat Jalan Pada Puskesmas Klangenan Kabupaten Cirebon.

Mahleni. (2019). Pengaruh Budaya Organisasi Dan Lingkungan Kerja Terhadap Kinerja Tenaga Kesehatan Di Puskesmas Gambir Baru Kabupaten Asahan Tahun 2018. Jurnal Mutiara Kesehatan Masyarakat. Sumatera Utara.

Prabu. (2017). Pengaruh Penghargaan dan Motivasi Terhadap Kinerja Karyawan. Jurnal Ekonomi Bisnis dan Kewirausahaan Vol. 5, No. 2. Surabaya.

Permenkes. (2014) Peraturan Menteri Kesehatan Republik Indonesia. Jakarta.

Profil Kesehatan Indonesia. (2017). Kementerian Kesehatan Republik Indonesia. Jakarta.

Profil Puskesmas Panambungan. (2019). Makassar.

P2PTM Kemenkes RI. (2018). 163 Tenaga Kesehatan dapat Penghargaan dari Menkes(http://www.p2ptm.kemkes.go.id/k egiatan-p2ptm/dki-jakarta/163-). Diakses 18/11/2020.

Rahma. (2016). Pengaruh Penerapan Konsep

$\begin{array}{lcr}\text { Team Work } & \text { Dan } & \text { Budaya } \\ \text { OrganisasiTerhadap } & \text { Kinerja } & \text { Perawat. } \\ \text { Journal Of Management Vol 5, } & \text { No. } 4 . \\ \text { Semarang. } & \end{array}$

Rukmini, Dkk, (2012). 408 Ketersediaan Dan Kelayakan Ruangan Pelayanan Puskesmas Berdasarkan Topografi, Demografi Dan Geografi Di Indonesia.

Rensiner, Dkk, (2018). Analisis Faktor Kualitas Pelayanan terhadap Kepuasan Pasien Rawat Jalan Rsud Dr. Achmad Darwis. Jurnal Kesehatan Andalas. Padang.

Rifai. (2020). Aspek keselamatan dan kesehatan kerja pada fasilitas pelayanan kesehatan di instansi kesehatan wilayah kerja Puskesmas Banguntapan III. JurnaPemberdayaan: Publikasi Hasil Pengabdian kepada Masyarakat.

Riana. (2019). Pengaruh Kerjasama Tim Dan Kepuasan Kerja Terhadap Kualitas Pelayanan. Jurnal psikologi. Samarinda.

Safriansyah, Dkk, (2019). Analisis Pengaruh Keamanan, Kesehatan dan Keselamatan Kerja terhadap Kinerja Pegawai Kantor Penanggulangan Bencana Kabupaten Majene. Jurnal Manajemen IKM Vol. 14, No. 1. Majene.

Tanu Wibowo, M. H. (2015). Pengaruh Budaya Organisasi Dan Motivasi Kerja Terhadap Kinerja Karyawan Pada Pt Lestari Purnama Perkasa. Vol. 3, No. 2.

Widiyanti. (2015). Pengaruh Disiplin Kerja, Motivasi Kerja, Gaya Kepemimpinan Kerja Terhadap Kualitas Kinerja Karyawan Dinas Kesehatan Kabupaten Sragen. SKRIPSI.

Yalitoba. (2019). Pengaruh Tambahan Penghasilan Terhadap Kinerja Pegawai Pada Sekretariat Daerah Kabupaten Sigi. Jurnal Journal of Social Welfare Vol. 6, No. 1. 